Ethiopian Journal of Environmental Studies \& Management 9(5): 653 - 665, 2016.

ISSN:1998-0507

doi: http://dx.doi.org/10.4314/ejesm.v9i5.11

Submitted: August 01, 2016

Accepted: October 06, 2016

\title{
ASSESSMENT OF FACILITIES IN MOTOR PARKS IN MINNA, NIGER STATE, NIGERIA, THROUGH POST-OCCUPANCY EVALUATION
}

*ADEDAYO, O.F. AND ZUBAIRU, S.N.

Department of Architecture, Federal University of Technology Minna, Niger State, Nigeria

\begin{abstract}
The use of motor parks and the importance they play in the sustenance of an urban area cannot be overlooked because the movement of commuters within and between urban areas is a constant activity. There are several motor parks in Minna and they cater for people from different walks of life hence there are different problems encountered by these users. The aim of this paper is to examine the user satisfaction with the facilities provided in the motor parks in Minna. In undertaking this research a post-occupancy evaluation of the motor parks was conducted using questionnaire and oral interview schedule. The facilities examined include the waiting areas, conveniences and the refreshment areas. A total of eight (8) motor parks were selected for the research and instruments were administered by research assistants. The data was collated and analysed using SPSS and the charts produced using Microsoft Excel software. The results show that $71 \%$ of the users of motor parks were not satisfied with the facilities provided within the motor park, while it was discovered that the majority of the motor parks were in a state of disrepair thereby needing maintenance. The paper concludes that there is a need to renovate the motor parks and provide good facilities for the users. It also stated that there is a need for a maintenance schedule for each of the motor parks with emphasis on cleaning.
\end{abstract}

Key Words: Maintenance, Motor park, Public space, Satisfaction, Users

\section{Introduction}

The concept of public space is one that varies depending on the background and cultural disposition of the respondents involved in the study. A common public space that is found in every urban area in Nigeria is a motor park or bus station with designs and physical layout, and services provided. Abel (2006) stated that a public space can either be a closed space or an open space. The major requirement of any end-user in a motor park is satisfaction and an examination of motor parks will reveal that they comprise of both indoor spaces and outdoor spaces which form public spaces and according to Smart et al. (2009) the quality to service which includes space and facilities is important to customer satisfaction with such space.

*Corresponding Author: Adedayo, O.F. 
The importance of a motor park is due to the large number of people that make use of public transport systems. Ogbazi, (1992) public transport is a system in which a greater number of people are moved at a time along principal corridors. Litman (2016), there is always the need to seek improvements for the public transport systems in any country as this gives the customers high sense of satisfaction.

It is believed that motor parks came into existence as a response to the need for central collection points of passengers and goods as commercial activities and population increase (Osaghe, 1972). The importance of transportation in any given city to its survival cannot be overemphasized as it is responsible for the movement of people in and around the city (Onokala, 2001). A visit to some selected motor parks in Nigeria shows an environment not conducive for commuters and operators. The aim of this study is to examine motor parks in the study area with the view of determining their problems and users perception of the motor parks. The satisfaction of the customer is the desire of any service provider hence that of the commuter should be the desire of the motor park providers (Anable, 2005).

In many developed countries public transportation systems provide the most efficient means of moving large number of people especially in densely populated urban centres and the comfort of the commuters is paramount (Iseki et al., 2007). The transportation system range from road, rail to air, while the airports and railway system have been fully developed, the road transport system has been the focus of many researchers in the developed countries. According to Iseki et al. (2007) the relative importance of stops at stations influences how commuters make their choice during bus transit. Evans (2004), Koonce et al. (2006) and Fruin (1985) stated that the environment of the stations is not a problem in the developed countries because solutions have been provided to the problems highlighted by these researchers.

World Bank report of 2001 stated that public transportation plays an important role in the productivity of cities; this view was also shared by Lyndon \& Todd (2006). In developing countries such as Nigeria inadequate attention has been placed on public transportation and this could be one of the reasons for the nature of the motor parks in its major cities. The problems of the nature of facilities in motor parks that have been addressed in developed countries have not been examined in Nigeria to provided solutions that fit Nigeria. In other to improve the motor parks and bus stations there is always the need to evaluate the existing facilities from the user viewpoint.

The growth of the public transport schemes has also brought about an increase in the number of motor parks in urban centres and variations in their design and operation. In Nigeria, Egunjobi (1999) viewed urban transport as serving as the sinew, binding together various land uses but has still remained inefficient, he concluded that urban transportation has grown over the years to become expensive and cumbersome and the facilities provided are not properly maintained. According to Adesanya and Adeniji (1998) urban transport in many Nigerian cities, exhibits remarkable features in terms of 
their operation, the nature of facilities provided and the designs of the motor parks. The Motor Park has almost all the features of an airport however, the airports appear better planned and maintained from an architect's viewpoint. The ground is well covered with asphalt, there are well-covered loading bays, arrival and departure lounge with ten split air-conditioning machines, there are alluring shops, a canteen, toilets, communication cubicle and dedicated transformer. From the foregoing, it is thus a possible reality that Motor Parks in Nigeria can be designed and maintained as standard facilities to satisfy the needs of the users in terms of comfort with the facilities provided. In Some Nigerian cities, inadequate management of motor parks has led to problems associated with large quantities of waste generation, insecurity, traffic which has become a serious issue for the government and the general public (Titus et al., 2010). It is common practice in the administration of many motor parks in Nigeria to find the organised union executives drawn from the operators of the park being responsible for the day to day running of the park. This form of organisation is viewed as being responsible for the nature and level of maintenance of the facilities provided in these parks.

In many motor parks found across the country they are usually made up of open areas for the cars, buses or vans to park, while there is usually provision for an administrative office, rental shops and limited sitting area for commuters. It is against this backdrop that Minna, Niger State was selected as the study area for this research.

\section{Research Method}

The research was undertaken in Minna, Niger state in North central part of Nigeria this region is covered under two Local Government Areas of Bosso and Chanchaga as shown in figure 1a, the geographical coordinates are given as $9^{\circ}$ 36' 50" North, 6 ${ }^{\circ} 33^{\prime} 2^{\prime \prime} 5^{\prime \prime}$ East; this allowed for a good mix of respondents with varied ethnic and cultural backgrounds. A post-occupancy evaluation (POE) was carried out on the motor parks with the use of a structured questionnaire and observation instruments to gather data. POE provides a mechanism for understanding the mutual interaction between buildings and users aspirations and for proposing ways of improving the environment necessary to accommodate these aspirations Vischer (2002). In addition, according to Watson (2003), POE serves as a multifaceted tool to account for building quality through the identification of successful design features, redundant or unnecessary building features, problems to mitigate, and defects to rectify. 


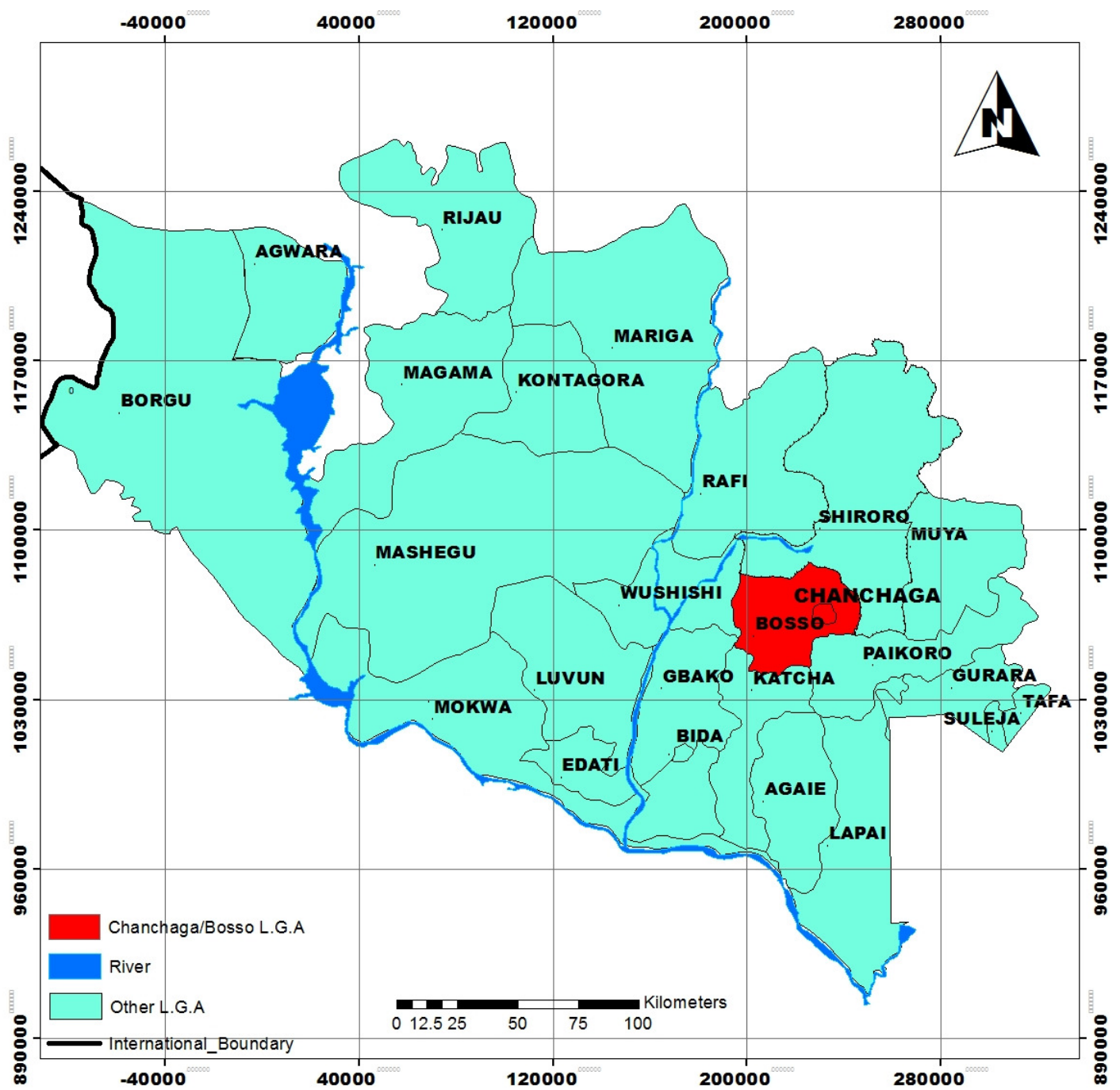

Figure 1a: Minna area under two Local Government Area of Bosso and Chanchaga. Source: Federal University of Technology (2016).

Table 1: Selected Motor parks in Minna state, Nigeria and their Locations

\begin{tabular}{ll}
\hline Motor Park & Location \\
\hline Paida Motor Park & Maitumbi road Minna \\
Abdulsalam Motor Park & Along Minna - Paiko road \\
Kpakungu Motor Park & Minna - Bida road \\
Gwadabe Motor Park & Near Old Minna Market \\
Niger State Transport Authority (NSTA) Park & Along Minna - Paiko road \\
Kure New Market Motor Park & Minna Central Market \\
Mobil Motor Park & Minna City Centre \\
Minna Central Motor Park. & Minna City Central area \\
\hline
\end{tabular}


The use of the questionnaire allowed commuters to respond to the questions while waiting to embark on their trip. The observation method adopted also allowed for the research assistants to document the physical appearances of the motor parks. The limitation with this form of data gathering instrument is that it is time consuming hence the use of research assistants to overcome the limitation. The research covered (8) eight motor parks located within Minna Niger state as shown in Table 1.

The survey of the motor parks spanned a period of 8 weeks with visits to the motor parks on different days and at different times of the day so as to obtain data from different commuters. The motor parks were grouped based on the proximity of their location so as to make the administering of the questionnaires easier and better organized. A total of 400 questionnaires were administered in the study area and this was spread evenly across the 8 motor parks. The data generated from the fieldwork was analysed using SPSS software. The results were transferred to Microsoft Excel which was used to generate the charts and graphs for the study which are presented in the discussion of results.

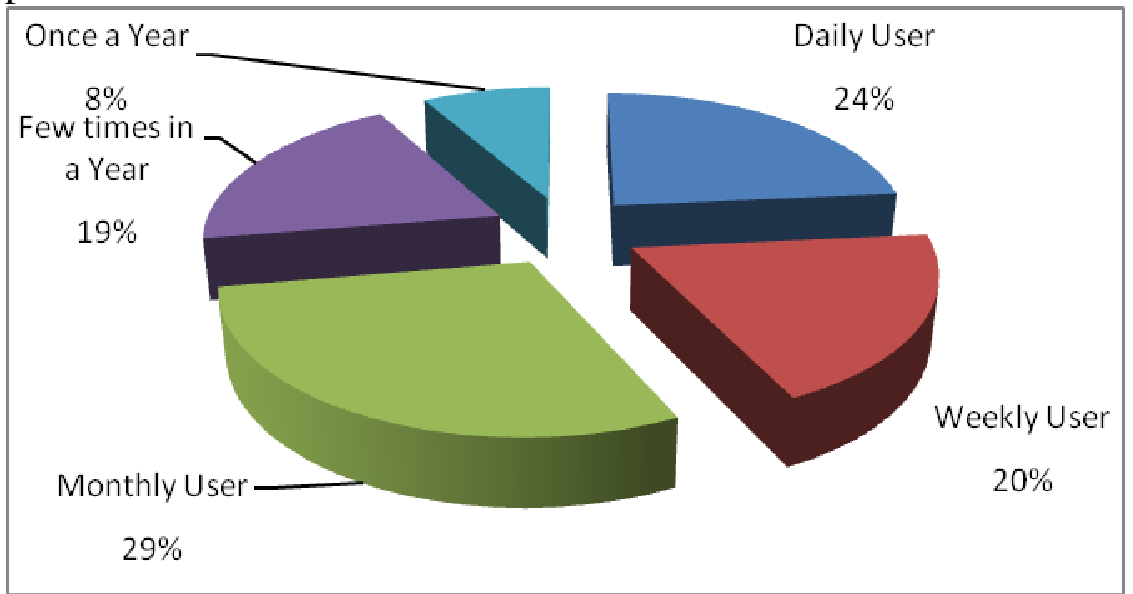

Figure 1: Average Distribution of Usage of Motor parks

\section{Results and Discussion Usage of the Motor Parks}

The average percentage distribution of the usage of the motor parks in Minna is shown in figure 1 where $49 \%$ of the respondents use the motor parks at least once a week. This implies that the motor parks can be considered as being quite functional and that the users make use of the facilities available within the park. The group that makes use of the park monthly are those who usually travel between towns for business or work purposes. This group usually require certain facilities such as good restaurants while the case of the $24 \%$ daily users are more interested in conveniences and waiting area. It can be concluded that the motor parks are in constant use all through the year and this affects the maintenance level of the facilities within the motor parks. The duration spent within the motor park varied amongst users hence their needs and perception would vary. Their perception would help improve the facilities within the motor parks because the managers and developers would meet the exact need of the users which supports the assertion of Afon et al. (2006). 


\section{Waiting time for trip}

The common expectation of the commuters in motor parks is to spend minimum time at the park before embarking on their journey. This expectation would have been met if the park was organised and if there was a time schedule for different trips. In the survey conducted it was discovered as shown in figure 2 that $88 \%$ of the respondents spend more than 15 minutes waiting for their trip to commence. The $12 \%$ that spend between 0-15 minutes are those who are making short intra-city trip. The time spent waiting for the journey to commence should be spent in a good waiting lounge however this is not the case as majority of the respondents usually wait in the car in the open parking area. This waiting period is considered by the respondents as quite an unpleasant period because of the lack of comfort. This lack of comfort affects the behaviour of the users of such facilities hence the need to improve the motor park because while waiting at the park their needs must be met and this is difficult to achieve as the facilities fall short of their expectation and according to Iseki et al (2007) perception studies of motor parks would help understand the nature of the facility with view of improving it.

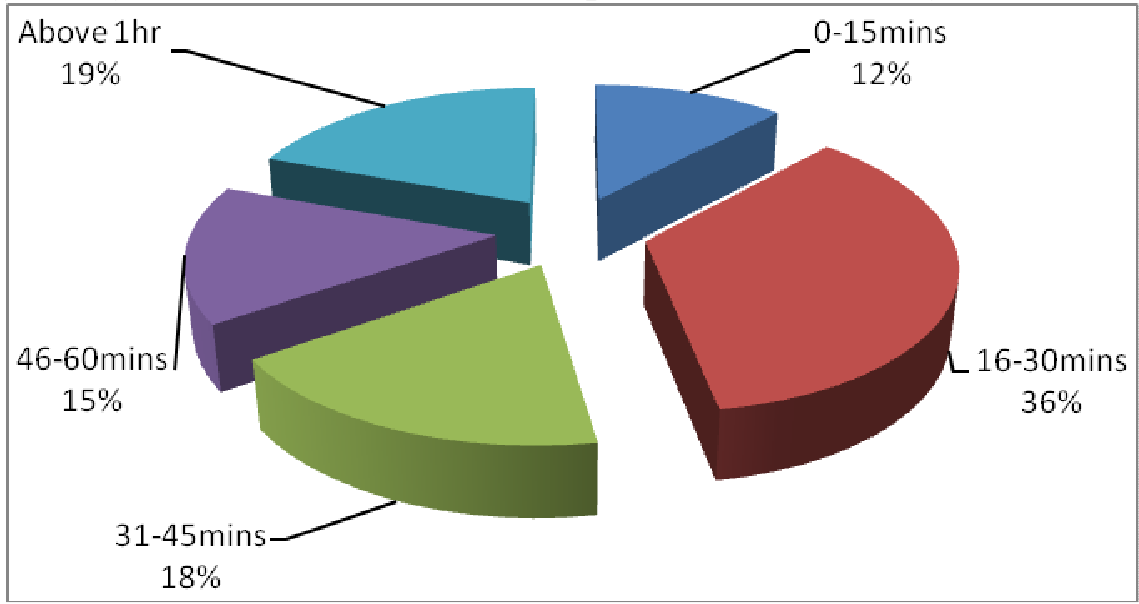

Figure 2: Average Distribution of Waiting time in Motor parks

\section{Waiting areas in Motor Parks}

A waiting lounge is expected to be known to every commuter who makes use of the motor park. It was observed from the evaluation that Mobil Motor Park, Central Motor Park and Old Gwadabe-Market Motor Park did not have any waiting area. It was therefore common to find commuters standing or sitting inside the cars they were to travel in. In Paida and Kpakungu motor parks the waiting area had been converted into dining area by local food vendors for passengers or park workers who wished to eat. The other motor parks had waiting areas for passengers to sit, however; they were often far from boarding areas for the commuters hence passengers did not make use of them as expected. This is one of the reasons why figure 3 showed that $64 \%$ of the respondents were not aware that there are waiting areas within the motor parks. Kure New Market and NSTA Motor Park had good waiting areas because they had adequate space for commuters to sit while waiting to 
make the trip. The seats in these motor parks could be improved and increased to accommodate the different users of the park which should increase the utilization of the space which also increases their comfort within the facilities. Litman (2016), stated that waiting time for commuters in motor parks was important in management of the stations hence the need to ensure that they are kept comfortable of which the waiting lounge is important hence the need for improvements as many commuters never bother to wait at transport stations.

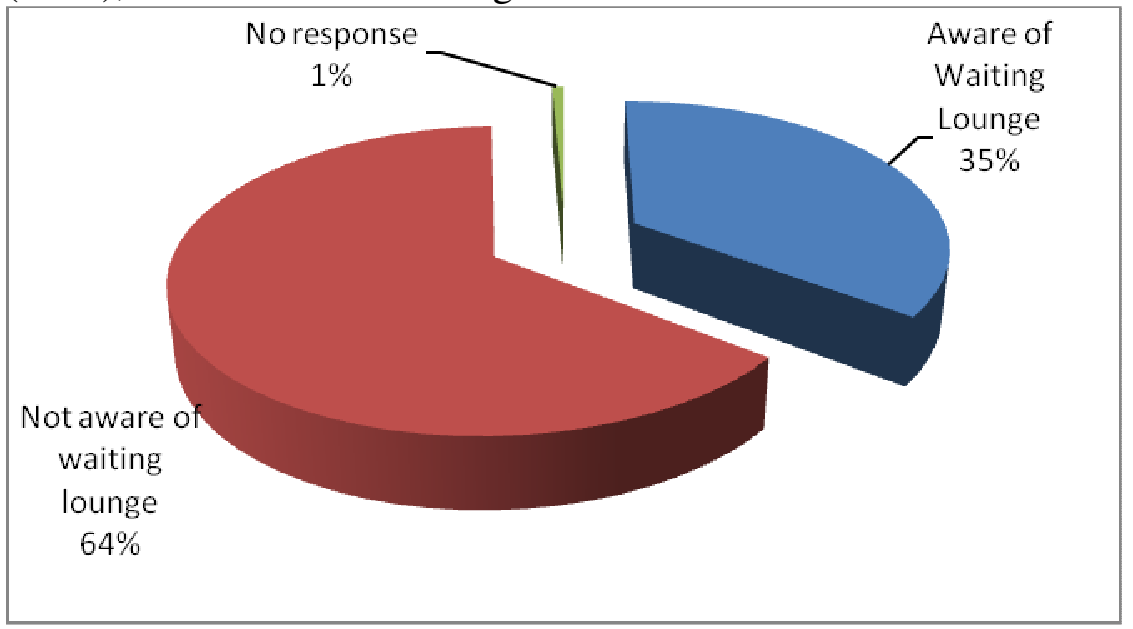

Figure 3: Average Distribution of Awareness of provision of Waiting Area in the Motor parks

In majority of the motor parks visited the lack of organisation is of the parking space and the distance of the waiting lounge to the vehicles parking space is quite large so commuters do not bother looking for the lounge. People usually standing by cars or sit inside the cars or on benches by the cars they intend to travel with.

The satisfaction of the commuters with facilities provided within the motor park is a measure of determining if the facility meets the purpose for which it was meant for. In figure $4,71 \%$ of the respondents were not satisfied with the waiting area. A few of the reasons cited for the lack of satisfaction were: the inadequate space provided, the lack of comfortable seats and the lack of proper maintenance of the waiting area with particular reference to the lack of cleaning of the area. The design of the waiting areas is usually open air which exposes commuters to direct environmental problems such as wind, dust and direct sunlight. 


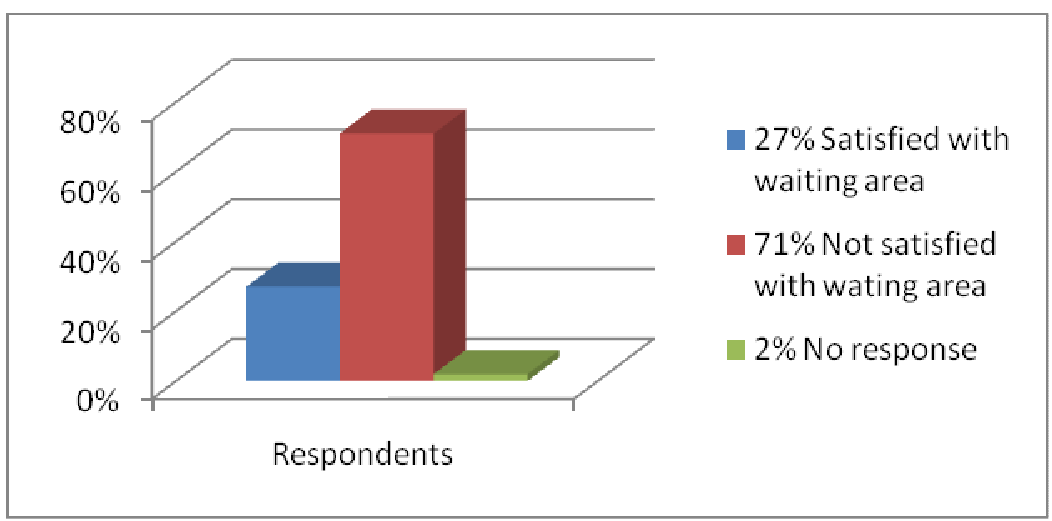

Figure 4: Satisfaction level with waiting area in the Motor parks

\section{Provision of Toilets in Motor Parks}

The provision of toilet facilities is a necessity in a motor park as commuters very often wait for over 15 minutes before they can embark on their journey. Figure 5 shows that $55 \%$ of the respondents were not aware of the provision of toilets in the motor park. This implies that should the need arise for them to ease themselves they are most likely to either seek out nearby bushes or uncompleted buildings. In many of the motor parks visited the commuters are expected to pay a token of between 10to 20 naira before being allowed to use the toilet. A few of the respondents were of the opinion that commuters should ease themselves at home before coming to the park and that while at the park they should watch what they ate so as to avoid the need for toilet. It was observed during the study that Abdulsalam Motor Park, Kure New Market Motor Park and NSTA Motor Park were the only motor parks that had good toilet facilities.

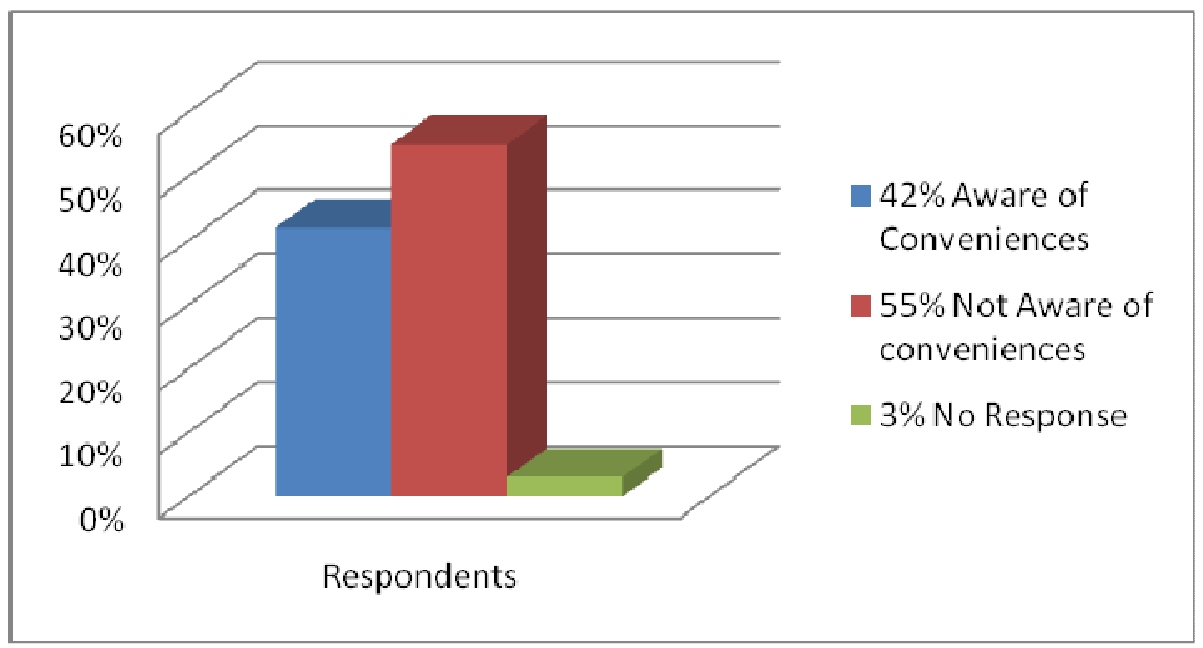

Figure 5: Awareness of provision of Toilets in the Motor parks

The type of toilets provided in majority of the motor parks is often a far cry from what the ideal situation should be. Figure 6 shows that $68 \%$ of the 
respondents were not satisfied with toilet facilities provided in the motor parks in Minna, because many were poorly managed while others had no roof and were just bounded by corrugated roofing sheets.

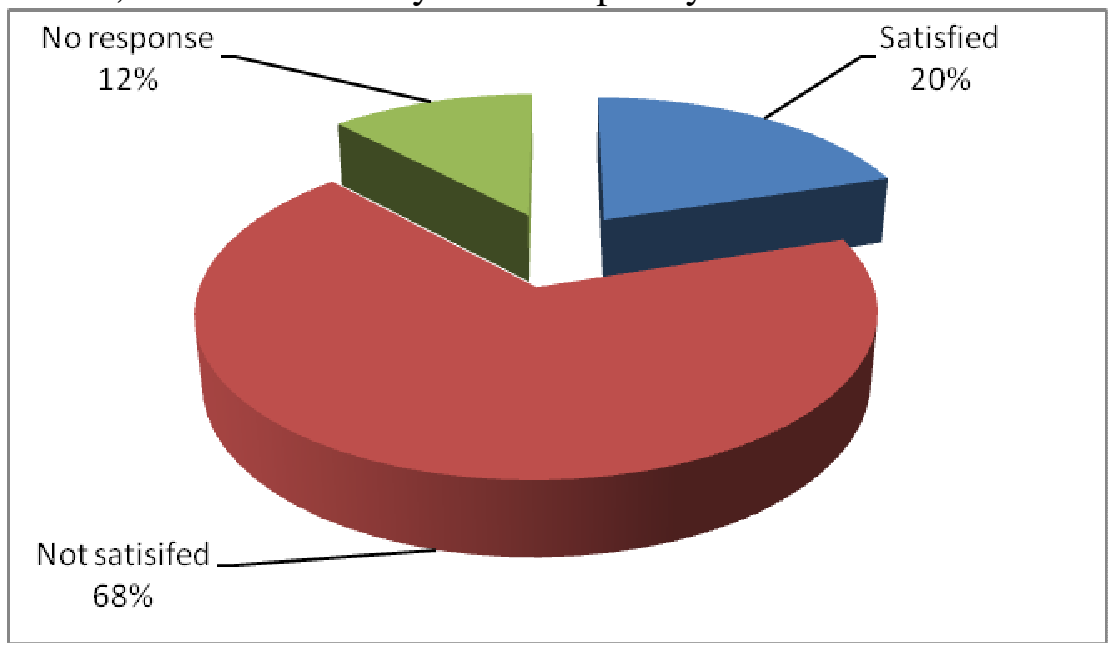

Figure 6: Satisfaction level with toilet facilities in the Motor parks

\section{Refreshment Facilities}

Majority of the motor parks are designed with rental shops which are operated by different shop owners who pay rent to the owner of the motor park. In figure 7 it is observed that $65 \%$ of the respondents are aware of the refreshment facilities provided within the motor parks. The use of some of the shops for restaurant purposes is common in all the motor parks while there cases of food vendors who hawk food in the park. The $31 \%$ of respondents that were not aware of the refreshment facilities were of the opinion that the refreshment facilities should be like those of conventional restaurants within the city. They implied that any refreshment facility not like the type within the city is not considered acceptable.

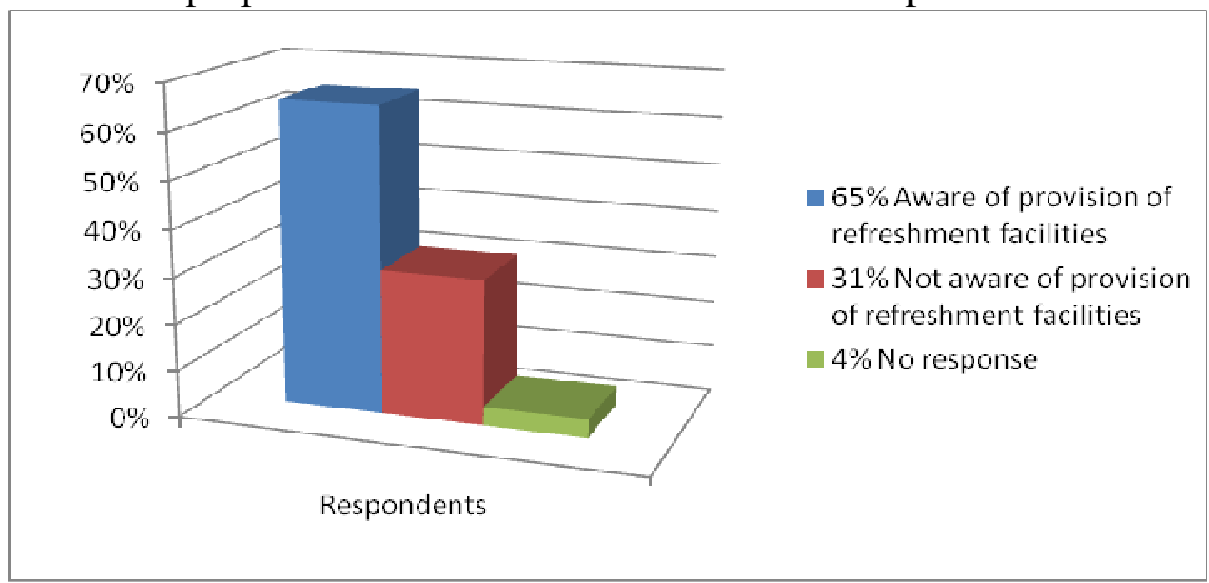

Figure 7: Average Distribution of Awareness of provision of Refreshment facilities in the Motor parks 


\section{User Satisfaction with Motor Parks}

Finally respondents were asked to state their satisfaction with the motor parks. From figure 8 it can be observed that $64 \%$ of the respondents are not satisfied with the facilities in the motor parks. The reasons for these perceptions range from the administration of the motor park to the facilities within the park to the design and arrangement of the motor park. The desire of majority of the respondents was to have similar comfort level they believed are available in airports and what they view in movies that depicted comfortable stations in developed countries in the motor parks. The chart in figure 8.0 shows that the motor parks have failed in meeting the comfort of the users and hence the patronage of these motor parks is due to the lack of alternatives.

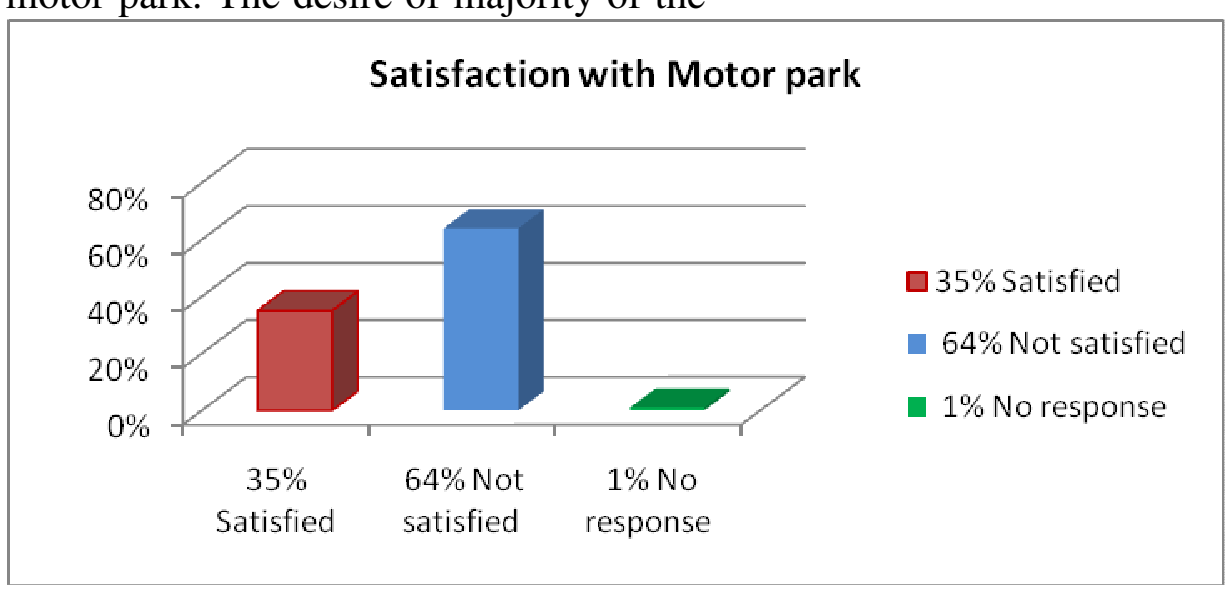

Figure 8: Average Comfort Satisfaction the Motor parksin Minna

\section{Observation Schedule Findings}

It was observed during the survey that the motor parks had different facilities available to the commuters. The quality of these facilities vary hence they are categorised as shown in table 2.0. It can be observed that the conditions of the restaurants in the motor parks where available are poor as many of them are not properly maintained. The floors were dirty while many had broken or cracked ceiling boards. It the case of waiting areas only two of the motor parks had good facilities particularly in terms of being neat; through there are no permanent seats at the Kure New Market Motor Park, plastic seats and benches are usually provided. It was observed that toilet facilities in Motor parks where they were available were not in good conditions. The three Motor parks that had good toilets were maintained by either the State government, Private Company or the Local government and the people responsible for it usually collected the toll and also had responsibility to keep it clean.

It was also observed that the level of maintenance in the different motor parks varied; Kure New Market Motor Park and NSTA Motor Park had the cleanest environment while Mobil Motor Park and Gwadabe Market had the least maintenance. The management of the motor park determined the type of schedule put in place for the maintenance 
of the park. The motor parks operated by the State government and a private company had better maintenance; these are; Kure New Market Motor Park, NSTA Motor Park and Abdulsalam Motor Park. The other motors parks were operated by the different transport unions. It was also observed that the motor parks that were purpose built such as Kure New Market Motor Park, NSTA Motor Park and Abdulsalam Motor Park had better facilities than the others which evolved overtime and had little or no planning. The most utilised space in any motor park is often the toilets as the need cannot be underestimated and it was discovered that only three motor parks were considered good. In addition the two motor parks that had good waiting area can be improved with better seats which would improve user's perception of the motor parks.

Table 2: Description of Selected facilities within Minna Motor Parks

\begin{tabular}{|c|c|c|c|}
\hline Facility & $\begin{array}{l}\text { Motor Parks with } \\
\text { Good Facility }\end{array}$ & $\begin{array}{l}\text { Motor Parks with } \\
\text { Poor Facility }\end{array}$ & $\begin{array}{l}\text { Motor Parks without } \\
\text { the Facility }\end{array}$ \\
\hline Toilets & $\begin{array}{l}\text { 1. Kure New Market Motor } \\
\text { Park } \\
\text { 2. Abdulsalam Motor Park } \\
\text { 3. Niger State Transport } \\
\text { Authority (NSTA) Park }\end{array}$ & $\begin{array}{l}\text { 1. Minna Central Motor } \\
\text { Park } \\
\text { 2. Kpakungu Motor Park }\end{array}$ & $\begin{array}{l}\text { 1. Paida Motor Park } \\
\text { 2. Mobil Motor Park } \\
\text { 3. Gwadabe motor park }\end{array}$ \\
\hline Waiting Area & $\begin{array}{l}\text { 1. Kure New Market Motor } \\
\text { Park } \\
\text { 2. Niger State Transport } \\
\text { Authority (NSTA) Park }\end{array}$ & $\begin{array}{l}\text { 1. Abdulsalam Motor } \\
\text { Park } \\
\text { 2. Paida Motor Park } \\
\text { 3. KpakunguMotor Park }\end{array}$ & $\begin{array}{l}\text { 1. Minna Central Motor } \\
\text { Park } \\
\text { 2. Mobil Motor Park } \\
\text { 3. Gwadabe Motor Park }\end{array}$ \\
\hline Refreshment Area & & $\begin{array}{l}\text { 1. Abdulsalam Motor } \\
\text { Park } \\
\text { 2. Paida Motor Park } \\
\text { 3. KpakunguMortorPark } \\
\text { 4. Minna Central Motor }\end{array}$ & $\begin{array}{l}\text { 1. Kure New Market } \\
\text { Motor Park } \\
\text { 2. Niger State Transport } \\
\text { Authority (NSTA) Park } \\
\text { 3. Mobil Motor Park } \\
\text { 4. GwadabeMotor Park }\end{array}$ \\
\hline
\end{tabular}

\section{Conclusion}

It has been discussed that a motor park falls under public space and its provision should be such that it takes into account the user needs and aspirations because this affects the success of such facilities. The research has shown that the motor parks have not met the needs of the users and hence it can be implied that the motor parks in Minna are inadequate and require major transformation. While some of the problems highlighted by the respondents can be solved by administrative means others require the renovation and redesign of parts or the entire motor park to reflect the desires of the users.

\section{Recommendations}

The paper concludes by making the following recommendations with the view that it would help improve the quality of the motor parks.

1. There should be maintenance evaluation of the motor parks with the view of determining the state of the buildings in the motor parks so as to determine the type of 
maintenance to be carried out within them.

2. Waiting lounges should be constructed in the motor parks that have none and the designs of such lounges should not be the open air type. In motor parks that have open air waiting areas they should be covered and furnished accordingly.

3. There should be provision of good conveniences within the motor parks, designed and constructed to the quality of the type found in international airports and provided with uninterrupted water supply.

4. The parking spaces in motor parks should be demarcated to ensure proper arrangement and orderly movement of vehicles.

5. A service company or service unit should be engaged to maintain the motor park in terms of cleaning of the facilities, while shop owners in the motor parks should be made to dispose of their waste properly.

\section{References}

Abel, F. (2006). Town Planning Handbook, Redwood press, Ile-Ife, Nigeria.

Adesanya, A.O. and Adeniji, S.A. (1998). "Sustaining urban public transport in Nigeria: critical issues and remedies" in Freeman \& Jamet (eds.) Urban Transport Policy. Balkema, Rotterdam, 775-781.

Afon, A.O., Abolade, O. and Okanlawon, S.A. (2006). User's Perception of Environmental Hazards and Risks as a Tool in Public Space Management: The Case of Selected Motor Parks in Lagos, Nigeria. Conference Proceeding of
Promoting Land Administration and Good Governance, 5th FIG Regional Conference, Accra, Ghana, March 8-11, 2006

Anable, J. (2005). 'Complacent Car Addicts' or 'Aspiring Environmentalists'? Identifying travel behaviour segments using attitude theory. Elsevier Journal of Transport Policy, $12 \quad 65-78$ Retrieved from www.elsevier.com on $13^{\text {th }}$ November 2012

Egunjobi, L. (1999). "Our Gasping Cities" An Inaugural Lecture delivered at the University of Ibadan on $21^{\text {st }}$ October 1999.

Evans, J.E. (2004). Chapter 9: Transit scheduling and frequency. TCRP report 95: Traveller Response to Transportation System Changes. Washington D.C.: Transportation Research Board.

Fruin, J.J. (1985). Passenger Information Systems for Transit Transfer Facilities. Retrieved from www.getcited.org on $13^{\text {th }}$ October 2012

Iseki, H., Ringler, A., Taylor, B.D., Miller, M. and Smart, M. (2007). Evaluating Transit Stops and Stations from the Perspective of Transit Users. Retrieved from www.its.ucla.edu/wpcontent/uploads/sites/6/2014/06/Ap pendix-C.pdfon 12th June 2016

Koonce, P., Ryus, P., Zagel, D., Park, Y. and Parks, J. (2006). An Evaluation of Comprehensive Transit Improvements-Trimet's Streamline Program. Journal of Public Transportation, 2006 BRT Special Edition 
Litman, T. (2016). Evaluating Public Transit Benefits and Costs Best Practices Guidebook. Retrieved from www.vtpi.org/tranben 3rd August 2016

Lyndon, H. and Todd, A.L. (2006). Evaluating New Start Transit Program Performance Comparing Rail and Bus. Victoria Transport Policy Institute Canada.

Ogbazi, J.U. (1992). Urban Transportation Planning. Principle and Practice of Urban and Regional Planning in Nigeria. Mekslink Publishers Nigeria, Awka. 64-72.

Onokala, P.C. (2001). Urbanization and Urban transportation problems in Nigeria, in E.O. Ezeani and N.N. Elekwe (eds) Issues in urbanization and urban administration in Nigeria Jamoe Enterprises (Nigeria) Publishers Enugu, 168-186

Osaghe, M. (1972). Benin City motor terminals and their spheres of influence cited in Adesanya, A.A.,
Location and Design of Inner-city Passenger Terminals: A Case of Abeokuta.

Smart, M., Miller, M. A. and Taylor, B. D. (2009). Transit Stops and Stations: Transit Managers' Perspectives on Evaluating Performance. Journal of Public Transportation, 12(1): 59-77

Titus, S.I., Andrew, E.D. and Mynepalli, K.C.S. (2010). Refuse disposal practices in three major motor parks in Ibadan municipality, Nigeria. Journal of Public Health and Epidemiology, 2(4): 82-86.

Vischer, J. (2002). Post Occupancy Evaluation: A Multifaceted Tool for Building Improvement, Federal Facilities Council, The National Academy Press, US , Chapter 3, 23 -34 .

Watson, C. (2003). Review of building quality using post occupancy evaluation, Journal of Programme Education Building, 35: 1 - 5. 